\title{
ANALISIS PERBANDINGAN KINERJA KEUANGAN PERBANKAN ASEAN (STUDI PADA BANK UMUM INDONESIA, THAILAND DAN FILIPINA)
}

\author{
Anggun Wahyuni \\ Mahasiswa Akuntansi Universitas Negeri Yogyakarta \\ Anggunwahyuni6@gmail.com \\ Sukirno \\ Dosen Pendidikan Akuntansi Universitas Negeri Yogyakarta
}

\begin{abstract}
Abstrak : Analisis Perbandingan Kinerja Keuangan Perbankan Asean (Studi Pada Bank Umum Indonesia, Thailand Dan Filipina). Penelitian ini bertujuan untuk mengetahui perbandingan kinerja keuangan industri perbankan Indonesia dengan negara ASEAN lainnya (Thailand dan Filipina) menggunakan indikator RGEC. Penelitian ini termasuk ke dalam penelitian komparatif. Populasi dalam penelitian ini adalah industri perbankan di Indonesia, Thailand dan Filipina. Pemilihan sampel menggunakan metode judment sampling. Seluruh sampel terdiri dari 3 bank di Indonesia, 3 bank di Thailand dan 3 bank di Filipina. Total sampel sebanyak 36 data termasuk didalamnya adalah sampel dengan periode 4 tahun $(2011,2012,2013$ dan 2014). Model statistik yang digunakan untuk menguji hipotesis menggunakan uji parametrik one-way ANOVA. Hasil penelitian menunjukkan bahwa seluruh indikator rasio keuangan perbankan Indonesia adalah signifikan berbeda dengan kinerja keuangan perbankan kedua negara ASEAN, kecuali rasio CAR. Rata-rata rasio keuangan perbankan Indonesia lebih baik dibandingkan dengan rata-rata tiga negara ASEAN lainnya pada rasio NPL, ROA, NIM dan CAR sedangkan rasio LDR menunjukkan lebih baik rata-rata negara ASEAN lainnya.
\end{abstract}

Kata kunci: $\quad$ Kinerja Keuangan Perbankan, ASEAN, RGEC, NPL, LDR, ROA, NIM, CAR

Abstract : Comparative Analysis Of The Asean Banking The Financial Performance (Studies On Commercial Bank Indonesia, Thailand And The Philippines. This study aims to compared of the financial performance of the Indonesian banking industry with other ASEAN countries (Thailand and the Philippines) using indicators RGEC. This studi was an comparating research. Population in this research was banking industry in Indonesian, Thailand and the Philippines. The sample selection using judment sampling methods. The whole sample consisted of three banks in Indonesia, 3 banks in Thailand and 3 banks in the Philippines. The total samples of 36 of data including the sample with a 4year period (2011, 2012, 2013 and 2014). Statistical models were used to test the hypothesis using ANOVA; parametric test one-way. The results showed that all indicators of the Indonesian banking financial ratios are significantly different. It is compared to the financial performance of banks both ASEAN countries, except CAR. The average financial ratios Indonesian banks is better than the average of the three other ASEAN countries in ROA, NIM, NPL and CAR ratio, while LDR better showing an average of other ASEAN countries.

Keywords: Financial Performance Banking, ASEAN, RGEC, NPL, LDR, ROA, NIM, CAR 


\section{JURNAL NOMINAL / VOLUME V NOMOR 2 / TAHUN 2016}

\section{PENDAHULUAN}

Era globalisasi ditandai dengan menyatunya negara-negara di dunia. Terbukanya perdagangan dunia dan perkembangan teknologi informasi yang semakin meluas akan berpengaruh pada dunia perbankan nasional dan pertumbuhan ekonomi. Perdagangan bebas regional maupun internasional merupakan awal dari dimulainya era globalisasi ekonomi. Di sisi lain, perbankan memiliki peranan besar karena peranan lembaga keuangan tidak bisa dipisahkan dari dunia usaha selain itu pertumbuhan ekonomi juga akan mengalami kenaikan dengan adanya berbagai kerjasama antar negara. Negaranegara yang tergabung dalam The Association of Southest Asian Nations (ASEAN) beranggotakan 10 negara, yaitu: Indonesia, Filipina, Thailand, Malaysia, Singapura, Brunei Darussalam, Vietnam, Laos, Myanmar, dan Kamboja. ASEAN dibentuk pada tanggal 8 Agustus 1967, memiliki tujuan utama membentuk kawasan Asia Tenggara menjadi kawasan yang aman. Salah satu kerjasama masyarakat ASEAN yaitu diresmikannya ASEAN Economic Community (AEC) atau diartikan sebagai Masyarakat Ekonomi ASEAN (MEA).

Salah satu sektor yang berpengaruh dalam AEC adalah industri perbankan, karena peranannya sebagai perantara lembaga keuangan yang semakin penting dan dibutuhkan untuk kelancaran kinerja perusahaan. Sektor perbankan sebagai lembaga perantara mempunyai peran yang besar dalam menggerakkan sektor riil. Kondisi bank yang tidak stabil tentu dapat memberikan dampak yang buruk bagi sektor ekonomi. Bank sentral masing-masing negara ASEAN terus berupaya melakukan pengawasan dan pembaharuan regulasi untuk mendorong industri perbankan agar selalu dalam keadaan sehat.

Pada kuliah umum Deputi Gubernur Senior Bank Indonesia menyampaikan kesiapan perbankan dalam menghadapi MEA 2015, dimana perbankan Thailand menunjukkan kemajuan yang baik, yaitu dengan jumlah bank yang tidak banyak, namun terdapat bank yang go international seperti Bangkok Bank. Sedangkan perbankan Filipina dilihat dari rasio Non Perfoming Loans ratio (NPL) dinilai masih lebih tinggi yaitu 2,4 \% dibandingkan perbankan Indonesia lebih rendah yaitu $1,9 \%$. Berbeda dengan kondisi perbankan di kedua negara tersebut, perbankan di Indonesia dinilai belum mampu bersaing secara maksimal. Dalam 10 bank terbesar di ASEAN, hanya bank Mandiri yang mampu masuk dalam jajaran tersebut. Sementara itu bank BRI dan Bank BCA masih berada di dua puluh besar. Namun demikian, perbankan Indonesia memiliki peluang yang besar untuk meningkatkan kapabilitas dan pertumbuhan Pendapatan Domestik Bruto nominal Indonesia yang positif dan pendapatan perkapita Indonesia yang mengalami pertumbuhan yang cukup stabil berdasarkan data World Bank tahun 2013. 


\section{JURNAL NOMINAL / VOLUME V NOMOR 2 / TAHUN 2016}

Selain itu, Perbankan Indonesia juga memiliki modal yang cukup bagus untuk bersaing dalam MEA, hal tersebut terlihat dari masuknya Bank Mandiri sebagai salah satu bank yang masuk dalam daftar Top 500 Banking Brands. Bank Mandiri terpilih dengan nilai valuasi merek sebesar US\$1,658 miliar, nilai ini lebih kecil dibandingkan valuasi merek negara Thailand dan Filipina (Ade Gunawan: 2014).

Pengukuran kinerja keuangan menggunakan rasio-rasio keuangan dalam RGEC sangat penting untuk mengetahui seberapa besar kemampuan perusahaan perbankan bersaing dengan perusahaan perbankan lainnya. Kekuatan sektor perbankan Indonesia tergolong kecil jika dibandingkan dengan negara ASEAN lainnya. Hal tersebut dilihat dari jumlah perbankan Indonesia yang masuk listing 15 di ASEAN hanya tiga, yaitu Bank Mandiri, Bank Rakyat Indonesia (BRI), dan Bank Central Asia (BCA). Dari sisi permodalan, Bank Mandiri peringkat delapan dengan modal US\$ 7,3 miliar, diikuti BRI peringkat 10 dengan modal US\$ 6,5 miliar, dan BCA peringkat tiga belas dengan modal US\$ 5,3 miliar, bahkan gabungan ketiga bank ini masih dibawah modal DBS. Berkaitan dengan kapitalisasi pasar, BCA peringkat ke enam senilai US\$ 19,4 miliar, diikuti Bank Mandiri peringkat ke delapan senilai US\$ 15,1 miliar, kemudian BRI peringkat sepuluh dengan nilai US\$ 14,7 miliar. (www.kompasiana.com) Dari data tersebut terlihat perbankan Indonesia belum terlalu kuat sebagai penyangga perekonomian Nasional dengan APBN Rp 2000 triliun dan GNP mendekati USD 500 miliar.

Dari alasan-alasan yang telah diuraikan diatas, sehingga sewajarnya perbankan di Indonesia mulai berbenah diri untuk menciptakan kinerja keuangan yang sehat. Dalam pasar bebas ASEAN, persaingan global pasar perbankan antar negara berjalan sangat ketat sehingga upaya mendorong efisiensi sektor perbankan yang berdaya saing tinggi harus terus dilakukan agar tidak tertinggal dengan negara lain.

Penelitian ini berusaha untuk membandingkan kinerja keuangan perusahaan perbankan melalui analisis rasiorasio keuangan untuk mengetahui seberapa jauh perbedaan kinerja keuangan perusahaan perbankan Indonesia dengan perusahaan negara ASEAN lainnya, terutama Thailand dan Filipina. Hal tersebut dikarenakan kesamaan level perekonomian nasional, dimana ketiga negara tersebut sama-sama menyandang gelar negara berkembang. Kinerja keuangan perbankan yang dilakukan dengan pendekatan analisis RGEC dari laporan keuangan perbankan di tiga negara ASEAN, dimana masing-masing negara diambil tiga bank yang memiliki core business (bisnis inti) dan market (pasar) di jalur yang sama. Hasil perbandingan tersebut akan menjadi stimulus bagi perbankan untuk 


\section{JURNAL NOMINAL / VOLUME V NOMOR 2 / TAHUN 2016}

saling berkompetisi dalam mencapai kinerja keuangan yang optimal.

Rochmawan (2004) melakukan penelitian tentang analisis indikator kinerja keuangan perbankan ASEAN (Studi Perbandingan Indonesia, Malaysia, Thailand, Filipina 2000-2002), menunujukkan bahwa seluruh indikator keuangan perbankan Indonesia adalah signifikan berbeda dengan kinerja keuangan perbankan ketiga negara ASEAN, kecuali rasio ROA dan ROE. Ratarata rasio keuangan perbankan Indonesia lebih baik dibanding rata-rata empat negara ASEAN lainnya yaitu untuk rasio CAR, NPL, ROL, LOA, ROE dan AGR, sedangkan CCA, RRA, EEA, LDR, dan ROA menunjukkan lebih baik rata-rata empat negara ASEAN lainnya. I Gusti Ayu Purnamawati (2014) melakukan penelitian tentang analisis komparatif kinerja keuangan perbankan ASEAN setelah krisis global, menunjukkan bahwa terdapat perbedaan signifikan antara indikator ROA, ROE dan LDR di tiga negara dan tidak terdapat perbedaan indikator CAR antara negara Indonesia, Thailand, dan Malaysia. Berdasarkan latar belakang masalah diatas maka penelitian ini bertujuan untuk mengetahui perbesaan kinerja keuangan perbankan di Indonesia, Thailand dan Filipina ditinjau dari aspek risk profile, earning dan capital.

\section{METODE PENELITIAN}

Penelitian ini merupakan penelitian komparatif. Penelitian komparatif merupakan penelitian yang bersifat membandingkan. Pendekatan yang digunakan dalam penelitian ini adalah pendekatan kuantitatif yaitu merupakan metode penelitian yang berlandaskan pada filsafat positivisme, digunakan untuk meneliti pada populasi atau sampel tertentu, pengumpulan data menggunakan instrument penelitian, analisis data bersifat kuantitatif atau statistik, dengan tujuan menguji hipotesis yang telah ditetapkan (Sugiyono, 2009: 8)

Populasi dalam penelitian ini adalah perusahaan-perusahaan perbankan di Indonesia, Thailand dan Filipina antara tahun 2011-2014. Pemilihan sampel penelitian dilakukan dengan metode judgement sampling yaitu merupakan teknik pengambilan sampel yang dilakukan berdasarkan kriteria yang ditetapkan terhadap elemen populasi target yang disesuaikan dengan tujuan atau masalah penelitian. Kriteria tersebut diantaranya perusahaan yang memiliki core business (bisnis inti) dan market (pasar) di jalur yang sama di negara Indonesia, Thailand dan Filipina, perusahaan yang masuk dalam kategori 3 bank terbesar dalam periode 2011-2014 serta telah menerbitkan laporan keuangan tahunana (annual report) pada tahun 2011, 2012, 2013, dan 2014. 
Tabel 1. Sampel Penelitian

\begin{tabular}{|c|c|c|}
\hline NO & NAMA BANK & $\begin{array}{l}\text { NEGARA } \\
\text { ASAL }\end{array}$ \\
\hline 1 & Bank Mandiri & \multirow{3}{*}{ INDONESIA } \\
\hline 2 & Bank Rakyat Indonesia & \\
\hline 3 & Bank Central Asia & \\
\hline 4 & Bangkok Bank & \multirow{3}{*}{ THAILAND } \\
\hline 5 & Siam Commersial Bank & \\
\hline 6 & Krung Thai Bank & \\
\hline 7 & Bank De Orobank & \multirow[b]{3}{*}{ FILIPINA } \\
\hline 8 & Metrobank & \\
\hline 9 & $\begin{array}{l}\text { Bank Of The Philippine } \\
\text { Island }\end{array}$ & \\
\hline
\end{tabular}

Metode analisis yang digunakan dalam penelitian ini adalah Kolmogorof Smirnov test dan uji parametrik one-way ANOVA.Variabel yang digunakan adalah kinerja keuangan bank di Indonesia, Thailand, dan Filipina. Variabel yang digunakan untuk menilai kinerja keuangan bank adalah analisis RGEC yang berupa rasio yang ada di Risk Profile, Earning, dan Capital. Rasio Risk Profile terdiri dari LDR dan NPL, serta rasio Earning diwakili oleh rasio ROA dan NIM. Sedangkan rasio Capital diwakili oleh CAR.

$$
\mathrm{LDR}=\frac{\text { Total Kredit }}{\text { Dana Pihak Ketiga }} \times 100
$$

Rasio ini untuk mengukur kemampuan bank dalam membayar kembali kewajiban kepada nasabah yang telah menanamkan dananya dengan menarik kembali kreditkredit yang telah diberikan kepada para debiturnya, jadi semakin tinggi rasio menunjukkkan tingkat likuiditas yang lebih baik (Rochmawan, 2004: 43).
$\mathrm{NPL}=\frac{\text { Kredit bermasalah }}{\text { Total Kredit }} \times 100 \%$

Rasio ini untuk mengukur seberapa besar kualitas aktiva produktif sehubungan dengan kredit bermasalah, jadi semakin rendah rasio menunjukkan kualitas aktiva produktif yang baik (Rochmawan, 2004: 42)

$$
\mathrm{ROA}=\frac{\text { Laba sebelum pajak }}{\text { Rata-rata total aset }} \times 100 \%
$$

Rasio ini menunjukkan kemampuan bank dalam mengelola aktiva yang dikuasainya untuk menghasilkan laba, jadi semakin tinggi rasio menunjukkan hasil yang semakin baik.

$\mathrm{NIM}=\frac{\text { Pendapatan bunga bersih }}{\text { Rata-rata aktiva } \text { produktif }} \times 100 \%$

Rasio ini menggambarkan tingkat jumlah pendapatan bunga bersih yang diperoleh dengan menggunakan aktiva produktif yang dimiliki oleh bank, jadi semakin besar nilai NIM akan semakin besar keu/ntungan yang diperoleh dari pendapatan bunga.

$$
\mathrm{CAR}=\frac{\text { Modal }}{\text { ATMR }} \times 100
$$

Rasio ini untuk mengukur kemampuan permodalan bank dalam menutup kemungkinan kerugian didalam kegiatan perkreditan dan perdagangan surat-surat berharga lainnya, jadi semakin tinggi rasio menunjukkan permodalan yang baik (Rochmawan, 2004: 41). 


\section{JURNAL NOMINAL / VOLUME V NOMOR 2 / TAHUN 2016}

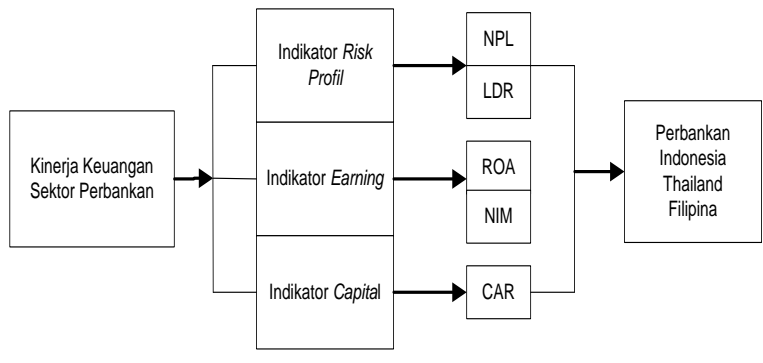

Gambar1. Paradigma Penelitian

Teknik analisis data yang digunakan dalam penelitian ini adalah analisis statistik diskriptif yaitu statistik untuk menganalisis data dengan cara mendeskripsikan atau menggambarkan data yang telah terkumpul sebagaimana adanya, tanpa bermaksud membuat kesimpulan yang berlaku umum (Sugiyono, 2015).

Uji asumsi klasik dalam penelitian ini mencakup uji normalitas dan uji homogenitas. Uji normalitas data bertujuan untuk menguji apakah data dalam model regresi berdistribusi normal atau tidak normal (Ghozali, 2011: 160). Model distribusi data yang baik adalah memiliki distribusi normal. Pengujian normalitas data dilakukan dengan uji Kolmogorof-Smirnov. Jika angka signifikansi Kolmogorof-Smirnov Sig. > 0,05 maka menunjukkan bahwa data berdistribusi normal. Sebaliknya jika angka signifikansi Kolmogorof-Smirnov Sig. $<0,05$ maka menunjukkan bahwa data tidak berdistribusi normal.

Uji homogenitas adalah uji variabel dependen untuk mengetahui apakah variabel memiliki varian yang sama dalam setiap kategori variabel independen (Ghozali, 2011). Jika terdapat lebih dari satu variabel independen, maka harus ada data homogeneity of variance di dalam cell yang dibentuk oleh variabel independen. Uji Homogenitas ini dinamakan Levene's test of Homogeneity variance. Jika Levene statistic signifikan > 0,05 maka hipotesis nol ditolak yang menyatakan grup memiliki varian sama. Jika hasil Levene test menunjukkan hasil probabilitas signifikan yang berarti varian tidak sama atau nilai signifikansinya $<0,05$ maka hal ini tidak fatal untuk ANOVA dan analisis masih dapat diteruskan sepanjang grup memiliki ukuran sampel yang sama. (Ghozali, 2011: 75).

Uji hipotesis yang dilakukan menggunakan Analisis of Variance, Uji Post Hoc Test dan Uji Homogeneous Subset. Untuk menguji hipotesis yang diusulkan peneliti, maka uji yang dipilih adalah analisis of variance (anova). Analisis of variance (anova) digunakan untuk menganalisis variabel yang berupa nilai atau angka (numeral variable) dengan beberapa asumsi yang mendasarinya untuk membandingkan rata-rata kelompok yang ada. Analisis of variance dalam penelitian ini menggunakan uji parametrik One-Way ANOVA dengan tingkat signifikansi $\alpha=0,05$.

Uji Post Hoc Test digunakan untuk menguji seberapa besar perbedaan kinerja keuangan perbankan antar negara yang dilihat pada output Tukey test dan Bonferoni test . Tukey test dilakukan untuk sampel yang sama, 


\section{JURNAL NOMINAL / VOLUME V NOMOR 2 / TAHUN 2016}

sedangkan Bonferoni test untuk sampel yang berbeda. Apabila pada kolom mean difference terdapat tanda "*" maka terdapat perbedaan yang signifikan.

Uji Homogeneous subset bertujuan untuk menguji apakah grup kinerja keuangan perbankan antar negara ASEAN mempunyai perbedaan rata-rata yang tidak berbeda secara signifikan yang nantinya terkelompokkan dalam tiga subset yang berbeda. Jika tidak terdapat perbedaan yang signifikan maka ketiga sampel akan terkelompokkan ke dalam satu subset.

\section{HASIL PENELITIAN DAN PEMBAHASAN}

\section{Analisis Deskriptif}

Dalam tabel 2 memperlihatkan bahwa masing-masing rasio keuangan di Indonesia, Thailand dan Filipina menunjukkan nilai atarata (mean) yang berbeda. Berdasarkan analisis deskriptif pada Tabel 2, maka rasio keuangan tertinggi yaitu NPL pada perbankan Thailand, LDR pada perbankan Thailand, ROA pada perbankan Indonesia, NIM pada perbankan Indonesia, dan CAR pada perbankan Filipina. Sehingga, perbankan Indonesia lebih baik dibandingkan perbankan Thailand dan Filipina dalam rasio ROA dan NIM.
Tabel 2. Analisis Deskriptif

\begin{tabular}{lrrrrr}
\hline Indikator & N & Mean & $\begin{array}{c}\text { Std. } \\
\text { Deviation }\end{array}$ & Min & Max \\
& & & & \\
\hline NPL & 36 & 2,057 & 0,952 & 0,400 & 4,500 \\
\hline LDR & 36 & 80,745 & 12,595 & 60,120 & 110,810 \\
\hline ROA & 36 & 0,321 & 0,183 & 0,060 & 0,650 \\
\hline NIM & 36 & 0,584 & 0,149 & 0,370 & 0,900 \\
\hline CAR & 36 & 15,735 & 1,36 & 12,700 & 19,200
\end{tabular}

Sumber: Data Sekunder diolah, 2016

\section{Uji Normalitas Data}

Pengujian normalitas data bertujuan untuk mengetahui apakah variabel yang digunakan mempunyai distribusi normal atau tidak. Uji normalitas dalam penelitian ini menggunakan data nilai residual yang diuji dengan Kolmogorof-Smirnov (K-S) test melalui pengukuran $\alpha=5 \%$. Jika nilai Asymp Sig (2-tailed) lebih besar dari 0,05 maka data dikatakan normal (Ghozali, 2011). Berdasarkan tabel 3 hasil uji menunjukkan data terdistribusi normal kecuali Return On Assets (ROA) dan Net Interest Margin (NIM). Ketidak normalan data ini terjadi karena perbedaan mean dan median antar kelompok sehingga menyebabkan data tidak bisa diolah secara normal. Untuk mengatasi hal tersebut, peneliti melakukan teknik transformasi data. Transformasi data pada hakikatnya tidak mengubah data meski mengubah nilai datanya. Karena yang diubah adalah semua nilai data, sehingga perbedaan nilai tiap sampel akan tetap. Dari penyesuaian ini ditemukan perbaikan distribusi menjadi normal. 
JURNAL NOMINAL / VOLUME V NOMOR 2 / TAHUN 2016

Tabel 3. Uji Normalitas

\begin{tabular}{lrrrrr}
\multicolumn{1}{c}{ Indi } & N & Mean & $\begin{array}{c}\text { Stand. } \\
\text { Deviasi }\end{array}$ & KS-Z & \multicolumn{1}{c}{$\begin{array}{c}\text { Asym. } \\
\text { Kator }\end{array}$} \\
\cline { 1 - 4 } NPL & 36 & 2,057 & 0,951 & 0,647 & 0,797 \\
\hline LDR & 36 & 80,745 & 12,595 & 0,571 & 0,900 \\
\hline ROA* & 36 & 0,321 & 0,183 & 1,193 & 0,116 \\
\hline NIM* & 36 & 0,584 & 0,148 & 1,066 & 0,206 \\
\hline CAR & 36 & 15,735 & 1,36 & 0,461 & 0,984 \\
\hline
\end{tabular}

Sumber: Data Sekunder diolah, 2016

Keterangan: *) ditransformasikan

\section{Uji Homogenitas}

Uji homogenitas bertujuan untuk menguji variabel dependen untuk mengetahui apakah variabel memiliki varian yang sama dalam setiap kategori variabel independen (Ghozali, 2011). Berdasarkan hasil Levene test pada tabel 4 menunjukkan bahwa nilai $\mathrm{F}$ test sebesar 0,386 (NPL), 0,016 (LDR), 1,856 (ROA), 13,141 (NIM), 0,255 (CAR) dan untuk rasio NPL, LDR, ROA, dan CAR tidak signifikan pada $0,05(\mathrm{p}>0,05)$ yang berarti hipotesis nol tidak dapat ditolak yang menyatakan variance sama, berarti asumsi ANOVA terpenuhi. Data terdistribusi homogen kecuali Net Interest Margin (NIM) dengan nilai sig 0,000 atau $\mathrm{p}<0,005$. Menurut (Ghozali, 2011: 75) apabila ada data yang tidak homogen, sepanjang grup memiliki ukuran sampel yang sama maka tidak fatal untuk ANOVA dan analisis masih dapat diteruskan.

\begin{tabular}{lrrrr}
\hline Tabel 4. Uji Homogenitas \\
\hline & $\begin{array}{l}\text { Levene } \\
\text { Statistic }\end{array}$ & & & \\
\hline NPL & 0,4 & 2 & 33 & 0,683 \\
\hline LDR & 0 & 2 & 33 & 0,985 \\
\hline ROA & 1,9 & 2 & 33 & 0,172 \\
\hline NIM & 13 & 2 & 33 & 0 \\
\hline CAR & 0,3 & 2 & 33 & 0,777
\end{tabular}

Sumber: Data Sekunder diolah, 2016

\section{Uji Hipotesis}

Pada tabel 5 terlihat bahwa nilai $\mathrm{F}$ hitung NPL sebesar 11,970 dengan probabilitas 0,000 yang berarti $\mathrm{p}<0,05$ maka ke tiga group sampel mempunyai rata-rata NPL yang berbeda (signifikan). Sedangkan nilai $\mathrm{F}$ hitung LDR sebesar 35,038 dengan probabilitas 0,000 yang berarti $\mathrm{p}<0,05$ maka ke tiga group sampel mempunyai rata-rata NPL yang berbeda (signifikan). Dengan demikian menolak $\mathrm{H}_{0}$ dan mendukung $\mathrm{H}_{1}$ yaitu terdapat perbedaan yang signifikan dari indikator Risk Profile antara kinerja keuangan perbankan Indonesia dengan kinerja keuangan perbankan negara Thailand dan Filipina.

Tabel 5 terlihat bahwa uji $\mathrm{F}$ hitung ROA sebesar 60,304 dengan probabilitas 0,000 yang berarti $p>0,05$ maka ketiga kelompok sampel mempunyai rata-rata ROA yang berbeda (signifikan). Sedangkan nilai $F$ hitung NIM sebesar 65,519 dengan probabilitas 0,000 yang berarti $\mathrm{p}>0,05$ maka ketiga kelompok sampel mempunyai rata-rata NIM yang berbeda (signifikan). Dengan demikian menolak $\mathrm{H}_{0}$ mendukung $\mathrm{H}_{2}$, yaitu terdapat perbedaan yang signifikan dari 


\section{JURNAL NOMINAL / VOLUME V NOMOR 2 / TAHUN 2016}

indikator Risk Earning antara kinerja keuangan perbankan Indonesia dengan kinerja keuangan perbankan negara Thailand dan Filipina

Tabel 5. Uji One Way ANOVA

\section{Uji Post Hoc Test}

Hasil uji Post Hoc Test indikator Risk Profile pada tabel diatas menunjukkan rasio NPL perbankan Indonesia dengan Thailand terdapat perbedaan rata-rata 1,426 , NPL

\begin{tabular}{lrrrrr}
\hline & $\begin{array}{c}\text { Sum of } \\
\text { Squares }\end{array}$ & $\begin{array}{c}\text { D } \\
\text { f }\end{array}$ & $\begin{array}{c}\text { Mean } \\
\text { Squar } \\
\text { e }\end{array}$ & F & Sig. \\
\hline Between & 13,332 & 2 & 6,666 & 11,970 & 0,000 \\
Groups & & & & & \\
\hline Within & 18,378 & 3 & 0,557 & & \\
\hline Groups & & 3 & & & \\
\hline Total & 31,71 & 3 & & & \\
\hline Between & 3774,83 & 2 & 1887,4 & 35,038 & 0,000 \\
Groups & 3 & & & & \\
\hline Within & 1777,65 & 3 & 53,868 & & \\
Groups & 6 & 3 & & & \\
\hline Total & 5552,48 & 3 & & & \\
\hline Between & 0,921 & 2 & 0,461 & 60,304 & 0,000 \\
Groups & & & & & \\
\hline Within & 0,252 & 3 & 0,008 & & \\
Groups & & 3 & & & \\
\hline Total & 1,174 & 3 & & & \\
\hline \multirow{2}{*}{ Between } & 0,617 & 2 & 0,308 & 65,519 & 0,000 \\
Groups & & & & & \\
\hline Within & 0,155 & 3 & 0,005 & & \\
\hline Groups & & 3 & & & \\
\hline Total & 0,772 & 3 & & & \\
\hline Between & 0,004 & 2 & 0,002 & 0,001 & 0,999 \\
\hline Groups & & & & & \\
\hline Within & 64,758 & 3 & 1,962 & & \\
\hline Groups & & 3 & & & \\
\hline Total & 64,761 & 3 & & & \\
\hline
\end{tabular}

Sumber: Data Sekunder diolah, 2016

Uji $\mathrm{F}$ hitung pada rasio CAR sebesar 0,01 dengan probabilitas 0,999 yang berarti $\mathrm{p}<$ 0,05 maka ketiga kelompok sampel mempunyai rata-rata ROA yang tidak berbeda. Dengan demikian menerima $\mathrm{H}_{0}$ dan menolak $\mathrm{H}_{3}$, yaitu tidak terdapat perbedaan yang signifikan dari indikator Capital antara kinerja keuangan perbankan Indonesia dengan kinerja keuangan perbankan negara Thailand dan Filipina. rata-rata 0,33917 dan NPL Filipina dengan Thailand terdapat perbedaan 1,087. Sedangkan perbedaan LDR perbankan Indonesia dengan Thailand terdapat perbedaan rata-rata 16,359 , LDR Indonesia dengan Filipina terdapat perbedaan sebesar 8,286 dan LDR Filipina dengan Thailand terdapat perbedaan sebesar 24,645. Dengan demikian bila diuji dengan Post Hoc Test secara individu terdapat perbedaan antar group. Tabel 6. Uji Post Hoc Test

\begin{tabular}{|c|c|c|c|c|c|}
\hline $\begin{array}{l}\text { Depent. } \\
\text { Variable }\end{array}$ & $\begin{array}{l}\text { (I) } \\
\text { NEGARA }\end{array}$ & $\begin{array}{l}\text { (J) } \\
\text { NEGARA }\end{array}$ & $\begin{array}{c}\text { Mean } \\
\text { Differenc } \\
\text { e (I-J) }\end{array}$ & $\begin{array}{l}\text { Std. } \\
\text { Error }\end{array}$ & $\begin{array}{l}\text { Sig. } \\
(\mathbf{0 , 0 5})\end{array}$ \\
\hline \multirow[t]{3}{*}{ NPL } & Indonesia & Thailand & $1,426^{*}$ & 0,304 & 0,000 \\
\hline & Indonesia & Filipina & 0,339 & 0,304 & 0,513 \\
\hline & Thailand & Filipina & $1,087^{*}$ & 0,304 & 0,003 \\
\hline \multirow[t]{3}{*}{ LDR } & Indonesia & Thailand & $16,359^{*}$ & 2,996 & 0,000 \\
\hline & Indonesia & Filipina & $8,286^{*}$ & 2,996 & 0,024 \\
\hline & Thailand & Filipina & $24,645^{*}$ & 2,996 & 0,000 \\
\hline \multirow[t]{3}{*}{ ROA } & Indonesia & Thailand & $0,291^{*}$ & 0,035 & 0,000 \\
\hline & Indonesia & Filipina & $0,372^{*}$ & 0,035 & 0,000 \\
\hline & Thailand & Filipina & 0,087 & 0,035 & 0,075 \\
\hline \multirow[t]{3}{*}{ NIM } & Indonesia & Thailand & $0,310^{*}$ & 0,028 & 0,000 \\
\hline & Indonesia & Filipina & $0,223^{*}$ & 0,028 & 0,000 \\
\hline & Thailand & Filipina & $0,087^{*}$ & 0,028 & 0,010 \\
\hline \multirow[t]{3}{*}{ CAR } & Indonesia & Thailand & 0,015 & 0,571 & 1,000 \\
\hline & Indonesia & Filipina & 0,009 & 0,571 & 1,000 \\
\hline & Thailand & Filipina & 0,025 & 0,571 & 0,999 \\
\hline
\end{tabular}

Sumber: Data Sekunder diolah, 2016 


\section{JURNAL NOMINAL / VOLUME V NOMOR 2 / TAHUN 2016}

Hasil Post Hoc Test pada indikator Risk Earning pada tabel 6 diatas menunjukkan rasio ROA perbankan Indonesia dengan Thailand terdapat perbedaan rata-rata 0,291, ROA Indonesia dengan Filipina terdapat perbedaan rata-rata 0,372 dan ROA Filipina dengan Thailand terdapat perbedaan 0,080. Sedangkan perbedaan NIM perbankan Indonesia dengan Thailand terdapat perbedaan rata-rata 0,310, NIM Indonesia dengan Filipina terdapat perbedaan sebesar 0,223 dan NIM Filipina dengan Thailand terdapat perbedaan sebesar 0,087. Dengan demikian bila diuji dengan Post Hoc Test secara individu pada rasio ROA dan NIM terdapat perbedaan antar group.

Hasil Post Hoc Test pada indikator Capital yaitu rasio CAR perbankan Indonesia dengan Thailand terdapat perbedaan rata-rata 0,015, CAR Indonesia dengan Filipina terdapat perbedaan rata-rata 0,009 dan CAR Filipina dengan Thailand terdapat perbedaan 0,025. Maka pengujian menggunakan post hoc test secara individu tidak seluruhnya memiliki perbedaan antar grup, namun hanya sebagian saja.

\section{Uji Homogeneous Subset}

Tabel 7 pada indikator rasio NPL menunjukkan nilai signifikansi 0,513 yaitu menyatakan bahwa rata-rata NPL antara perbankan Indonesia dan Filipina (dalam satu subset) tidak berbeda secara statistik. Sedangkan nilai rata-rata NPL untuk perbankan Thailand berbeda dengan perbankan Indonesia

dan Filipina sehingga ada pada subset sendiri di kolom kedua. Pada indikator LDR menunjukkan nilai signifikansi 1,000 untuk negara Filipina, Indonesia dan Thailand. Hal ini menunjukkan bahwa nilai rata-rata antar negara ASEAN berbeda karena masing-masing negara berada pada kolom subset yang berbeda.

Tabel 7 pada indikator ROA menunjukkan nilai signifikansi 0,075 yaitu menyatakan bahwa rata-rata ROA antara perbankan Filipina dan Thailand (dalam satu subset) tidak berbeda secara statistik, sedangkan nilai rata-rata ROA untuk perbankan Indonesia berbeda dengan perbankan Filipina dan Thailand sehingga ada pada subset sendiri di kolom kedua. Pada indikator NIM menunjukkan nilai signifikansi 1,000 untuk negara Filipina, Indonesia dan Thailand. Hal ini menunjukkan bahwa nilai rata-rata antar negara ASEAN berbeda karena masing-masing negara berada pada 3 kolom subset yang berbeda.

Tabel 7 pada indikator CAR menunjukkan nilai signifikansi 0,999 yaitu menyatakan bahwa rata-rata CAR antara perbankan Thailand, Indonesia dan Filipina (dalam satu subset) tidak berbeda secara statistik. 
Tabel 7. Uji Homogeneous Subset

\begin{tabular}{|c|c|c|c|c|c|}
\hline \multirow[t]{2}{*}{ Rasio } & \multirow[t]{2}{*}{ Negara } & \multirow[t]{2}{*}{$\mathrm{N}$} & \multicolumn{3}{|c|}{ Subset for alpha $=0.05$} \\
\hline & & & 1 & 2 & 3 \\
\hline \multirow{4}{*}{ NPL } & Indonesia & 12 & 1,468 & & \\
\hline & Filipina & 12 & 1,807 & & \\
\hline & Thailand & 12 & & 2,895 & \\
\hline & Sig. & & 0,513 & 1,000 & \\
\hline \multirow{4}{*}{ LDR } & Filipina & 12 & 69,767 & & \\
\hline & Indonesia & 12 & & 78,054 & \\
\hline & Thailand & 12 & & & 94,413 \\
\hline & Sig. & & 1,000 & 1,000 & 1,000 \\
\hline \multirow{4}{*}{ ROA } & Filipina & 12 & 0,170 & & \\
\hline & Thailand & 12 & 0,250 & & \\
\hline & Indonesia & 12 & & 0,542 & \\
\hline & Sig. & & 0,075 & 1,000 & \\
\hline \multirow{4}{*}{ NIM } & Thailand & 12 & 0,451 & & \\
\hline & Filipina & 12 & & 0,539 & \\
\hline & Indonesia & 12 & & & 0,762 \\
\hline & Sig. & & 1,000 & 1,000 & 1,000 \\
\hline \multirow{4}{*}{ CAR } & Thailand & 12 & 15,721 & & \\
\hline & Indonesia & 12 & 15,737 & & \\
\hline & Filipina & 12 & 15,746 & & \\
\hline & Sig. & & 0,999 & & \\
\hline
\end{tabular}

Sumber: Data Sekunder diolah, 2016

\section{PEMBAHASAN}

\section{Indikator Risk Profile}

Hasil pengujian terhadap hipotesis 1 menunjukkan menolak $\mathrm{H}_{0}$ dan menerima $\mathrm{H}_{1}$ yaitu terdapat perbedaan yang signifikan dari indikator Risk Profile antara kinerja keuangan perbankan Indonesia dengan kinerja keuangan perbankan Thailand dan Filipina. Rata-rata Non Perfoming Loan (NPL) tertinggi adalah perbankan Thailand, kemudian Filipina dan Indonesia. Perbankan Indonesia menunjukkan rata-rata NPL paling rendah yaitu sebesar 1, 468 persen berarti semakin baik kualitas kredit perbankan Indonesia. Hanya perbankan
Indonesia yang menunjukkan rasio NPL paling rendah dari rata-rata perbankan ASEAN. Rendahnya NPL perbankan di Indonesia menjadikan kemampuan bank menciptakan pendapatan operasional lebih tinggi, karena kredit bermasalah yang rendah.

Sedangkan untuk rata-rata Loan to Deposit Ratio (LDR) tertinggi juga berada di negara Thailand yaitu sebesar 94,413 persen, kemudian Indonesia 78,054 persen dan Filipina 69,768 persen. Tingginya LDR yang tinggi pada perbankan Thailand, maka kemampuan bank dalam membayar kembali kewajibannya kepada nasabah juga semakin tinggi. Sedangkan posisi perbankan Indonesia berada di tengah-tengah antara perbankan Thailand dan Filipina.

Dengan demikian secara statistik rasio NPL dan LDR menunjukkan perbedaan antara perbankan Indonesia, Thailand dan Filipina. Indikator Rasio NPL perbankan Indonesia menunjukkan kualitas aktiva produktif yang baik sedangkan indikator rasio LDR masih di bawah perbankan Thailand. Penyebab LDR perbankan Indonesia lebih rendah hal ini karena sebelumnya bahwa perbankan nasional pernah mengalami kemerosotan jumlah kredit karena diserahkan ke BPPN untuk ditukar dengan obligasi rekapitalisasi. Begitu besarnya nilai kredit yang keluar dari sistem perbankan di satu sisi dan semakin meningkatnya jumlah DPK yang masuk ke perbankan, maka upaya ekspansi kredit yang dilakukan perbankan selama sepuluh tahun terakhir sepertinya belum 


\section{JURNAL NOMINAL / VOLUME V NOMOR 2 / TAHUN 2016}

berhasil mengangkat angka LDR secara signifikan.

\section{Indikator Risk Earning}

Hasil pengujian terhadap $\mathrm{H}_{2}$ menunjukkan menolak $\mathrm{H}_{0}$ dan menerima $\mathrm{H}_{2}$ yaitu terdapat perbedaan yang signifikan dari indikator risk profil antara kinerja keuangan perbankan Indonesia dengan kinerja keuangan perbankan Thailand dan Filipina. Dilihat dari rata-rata tiap negara, Indonesia memiliki nilai rata-rata Return On Assets (ROA) tertinggi yaitu sebesar 0,543 persen selanjutnya Thailand 0,251 persen dan Filipina 0,170 persen. Tingginya ROA di Indonesia disebabkan diantaranya rata-rata tingkat biaya overhead rendah dan kemampuan bank menciptakan pendapatan operasional juga tinggi. Selain itu, tingkat keuntungan bank yang tercermin dalam tingginya ROA di Indonesia dan Thailand menunjukkan bahwa aktiva bank yang telah digunakan dengan optimal untuk memperoleh oendapatan bank, sehingga perbankan di Indonesia mempunyai kemampuan yang lebih dalam menghasilkan keuntungan dari total aktiva yang dimiliki, apabila dibandingkan dengan perbankan Thailand dan Filipina. Hasil ini sama dengan penelitian yang dilakukan oleh Rochmawan (2004) yang menyatakan bahwa terdapat perbedaan yang signifikan antara rasio ROA antar negara ASEAN.

Terdapat perbedaan yang signifikan dari indikator risk profil antara kinerja keuangan perbankan Indonesia dengan kinerja keuangan perbankan Thailand dan Filipina dilihat dari rasio NIM. Rata-rata tertinggi rasio NIM juga berada di perbankan Indonesia yaitu sebesar 0,763 persen, selanjutnya Filipina 0,539 persen dan Thailand 0,452 persen. Tingginya NIM di Indonesia menggambarkan semakin besar keuntungan yang diperoleh dari pendapatan bunga dan akan berpengaruh pada tingkat kesehatan bank.

Dengan demikian indikator risk earning untuk ROA, perbankan Indonesia menunjukkan hasil paling baik karena nilai rata-ratanya diatas rata-rata perabankan ASEAN selain itu untuk rasio NIM perbankan Indonesia juga menunjukkan tingkat rata-rata paling tinggi dibanding dua negara ASEAN lainnya.

\section{Indikator Capital Risk}

Hasil pengujian terhadap hipotesis 3 menunjukkan menolak H3, yaitu tidak terdapat perbedaan yang signifikan dari indikator capital risk antar kinerja keuangan perbankan Indonesia, Thailand dan Filipina. Hampir semua perbankan menujukkan nilai rata-rata yang hampir sama. Namun bila dilihat secara rata-rata, maka nilai rata-rata CAR tertinggi adalah perbankan Filipina, kemudian Indonesia dan Thailand. Karena ketiga negara sama-sama negara berkembang sehingga aset perbankan yang dimiliki juga perbedannya tidak terlalu jauh. Tingginya rasio CAR perbankan Indonesia disebabkan karena paraturan Bank Indonesia yang mensyaratkan CAR minimal sebesar $8 \%$ mengakibatkan bank-bank selalu berusaha 


\section{JURNAL NOMINAL / VOLUME V NOMOR 2 / TAHUN 2016}

menjaga agar CAR yang dimiliki sesuai dengan ketentuan. Dengan demikian, indikator capital risk yang diwakili oleh Capital Adequacy Ratio (CAR) dinilai cukup kuat untuk bersaing sehat dengan perbankan lainnya dalam mengahadapi Masyarakat Ekonomi ASEAN (MEA). Secara empiris, hasil penelitian ini konsisten dengan penelitian I Gusti Ayu (2014).

Dari interpretasi tabel 8 terlihat bahwa perbankan Indonesia sesungguhnya dapat bersaing dengan negara ASEAN lainnya. Sebagian besar rasio keuangan perbankan Indonesia menunjukkan kinerja lebih baik dibandingkan dengan rata-rata perbankan Thailand dan Filipina. Namun di sisi lain pada indikator risk profile perbankan Indonesia masih dibawah rata-rata perbankan ASEAN. Sehingga perlu dilakukan pembenahan kinerja keuangan perbankan Indonesia oleh pihak otoritas moneter maupun industri perbankan itu sendiri dalam sistem pengawasan terlebih dalam pengelolaan kredit bermasalah karena pada tabel 8 diatas menunjukkan perbankan Indonesia berada pada posisi masih kurang. Sehingga dengan begitu perbankan Indonesia untuk mencapai keunggulan dalam persaingan sehat mengahadapi Masyarakat Ekonomi Asean (MEA) bisa terwujud.
Tabel 8. Perbandingan rata-rata kinerja keuangan perbankan Indonesia dengan dua negara ASEAN

\begin{tabular}{cccccc}
\hline Indi & Ind & Tha & Fil & ASEAN & $\begin{array}{c}\text { Lebih } \\
\text { kator }\end{array}$ \\
& $(\%)$ & $(\%)$ & $(\%)$ & & $\begin{array}{c}\text { Kurang) } \\
\text { Baik }\end{array}$ \\
\cline { 5 - 6 } & & & & & \\
\hline NPL & 1,468 & 2,895 & 1,808 & 2,057 & Lebih \\
\hline LDR & 78,054 & 94,413 & 69,768 & 80,745 & Kurang \\
\hline ROA & 0,543 & 0,251 & 0,17 & 0,321 & Lebih \\
\hline NIM & 0,763 & 0,452 & 0,539 & 0,584 & Lebih \\
\hline CAR & 15,738 & 15,722 & 15,747 & 15,735 & Lebih \\
\hline
\end{tabular}

Sumber: Data Sekunder diolah, 2016

\section{SIMPULAN DAN SARAN}

\section{Simpulan}

Penilaian terhadap indikator risk profile menunjukkan risiko kredit (NPL) ketiga negara ASEAN memiliki perbedaan kinerja keuangan yang berbeda. Hal ini terlihat bahwa nilai $\mathrm{F}$ hitung NPL sebesar 11,97 persen dengan probabilitas 0,000 yang berarti $\mathrm{p}<$ 0,05 yang menyatakan NPL mempunyai ratarata yang berbeda (signifikan). Perbankan Indonesia menunjukkan rata-rata NPL paling rendah yang menunjukkan kualitas aktiva produktif yang baik. Sedangkan nilai F hitung LDR sebesar 35,03 persen dengan probabilitas 0,000 yang berarti $\mathrm{p}<0,05$ yang menyatakan LDR mempunyai rata-rata yang berbeda (signifikan). Rata-rata LDR paling tinggi diperoleh perbankan Thailand, menunjukkan bahwa suatu bank meminjamkan seluruh dananya (loan-up) atau relatif tidak likuid. 


\section{JURNAL NOMINAL / VOLUME V NOMOR 2 / TAHUN 2016}

Penilaian terhadap indikator risk hampir sama, namun secara rata-rata perbankan earning pada rasio ROA yang digunakan untuk Filipina menunjukkan rata-rata CAR paling mengukur kemampuan manajemen bank dalam tinggi yang mengartikan semakin besar modal memperoleh profitabilitas dan mengelola yang dimiliki perbankan Filipina sehingga tingkat efisiensi usaha bank secara keseluruhan semakin rendah mengalami kondisi bermasalah memiliki perbedaan kinerja keuangan pada tiga pada bank.

negara ASEAN. Hal ini terlihat bahwa nilai F Saran hitung ROA sebesar 60,30 persen dengan Penelitian ini diharapkan dapat menjadi probabilitas 0,000 yang berarti $\mathrm{p}<0,05$ yang menyatakan ROA mempunyai rata-rata yang berbeda (signifikan). Perbankan Indonesia menunjukkan rata-rata tertinggi yang mengartikan tingkat rentabilitas usaha bank Indonesia semakin baik. Sedangkan nilai F hitung NIM sebesar 65,51 persen dengan probabilitas 0,000 yang berarti $\mathrm{p}<0,05$ yang menyatakan ROA mempunyai rata-rata yang berbeda (signifikan). Rasio NIM menggambarkan tingkat jumlah pendapatan bunga bersih yang dimiliki oleh bank. Rata-rata nilai NIM teratas diperoleh perbankan Indonesia yang mengartikan semakin besar keuntungan yang diperoleh dari pendapatan bunga dan akan berpengaruh pada tingkat kesehatan perbankan di Indonesia.

Penilaian terhadap indikator Capital menunjukkan rasio permodalan (CAR) pada tiga negara ASEAN memiliki persamaan yang hampir tidak jauh berbeda pada kinerja keuangan. Hal ini terlihat bahwa nilai F hitung CAR sebesar 0,01 persen dengan probabilitas 0,999 yang berarti $\mathrm{p}>0,05$ yang menyatakan CAR mempunyai rata-rata yang tidak berbeda. Walaupun indikator permodalan tiap negara 


\section{DAFTAR PUSTAKA}

Ade Gunawan. (2014). Perbedaan Kinerja Keuangan Perusahaan Perbankan dengan Nilai Valuasi Merek Tertinggi di ASEAN untuk Menghadapi MEA. Artikel Ilmiah. STIE MDP Palembang

Departemen Perdagangan. (2012). Мепијu ASEAN Economic Community 2015. Departemen Perdagangan Republik Indonesia. Direktorat Internasional Bank Indonesia

Dwi Prastowo. (2011). Analisis Laporan Keuangan Konsep dan Aplikasi. Yogyakarta: UPP STIM YKPN.

Fahmi, Irham. (2012). Analisis Kinerja Keuangan. Bandung: CV Alvabeta.

Ghozali, Imam. (2011). Aplikasi Analisis Multivariate dengan Program IBM SPSS 19. Semarang: Universitas Diponegoro.

I Gusti Purnamawati. (2014). Analisis Komparatif Kinerja Keuangan Perbankan Asean Setelah Krisis Global. Jurnal Keuangan dan Perbankan, Vol 18 No 2: 287-296

Ikatan Akuntan Indonesia. (2007). PSAK 1 Penyajian Laporan Keuangan Revisi 1998. Diakses melalui www.iaiglobal.or.id pada 10 Januari 2016 pukul 13.36

Jumingan. (2009). Analisis Laporan Keuangan. Jakarta : PT Bumi Aksara.

Kasmir (2008). Bank Dan Lembaga Keuangan Lainnya. Jakarta: PT Raja Rafindo Persada

Kasmir. (2008). Analisis Laporan Keuangan. Jakarta: Rajawali Pers.

M.L.T Rochmawan. (2004). Analisis Indikator Kinerja Keuangan Perbankan Asean (Studi
Perbandingan Indonesia, Malaysia, Thailand, dan Philippine 20002002). Tesis. Universitas Diponegoro.

Sugiyono. (2008). Statistika untuk Penelitian. Bandung: Alfabeta.

Yudhi Hertanto. (2014). Bagaimana kekuatan perbankan kita? Studi Kasus Ekonomi Asean. Diakses melalui www.kompasiana.com pada 12 Januari 2016 pukul 10.05 